Getting to grips with the globe

\author{
Gordon L. Herries Davies
}

To Interpret the Earth: Ten Ways to be Wrong. By Stanley A. Schumm. Cambridge University Press: 1991. Pp. 134. £20, \$24.95.

"THE moment I hear the word philosophy I reach for my hammer." Such, I suspect, might be the sentiment of many a geologist, and for that reaction I am prepared to hazard an explanation. Geology likes to be perceived as a science abounding in machismo. This is clearly a delusion (worthy sisters have long since infiltrated 'the brethren of the hammer'), but many of us do still think of geologists as blokes who are burly and bearded, booted and bluff, beery and bawdy.

\section{Hard-rock men}

Certainly in the United Kingdom there is within the science itself a graded gender scale. Really masculine geologists grapple with the Palaeozoic era and older problems; those who dally with the Mesozoic and Tertiary periods are geologists only on sufferance; and those having affairs with the Quaternary are first branded as geomorphologists and then banished into the anile field of geography. Real British geologists are 'hard-rock men' (freudians will note the adjectives) and 'soft-rock men' feel just a teeny-weeny bit inadequate.

Now I imagine that most geologists, when pressed, would admit to regarding philosophy as an effete discipline - a discipline still more remote from the hard core of geology than is geomorphology - and it may be that many geologists imagine that their personal image would suffer through too close an involvement with philosophical issues. Here we may have an explanation for the fact that so many geologists go forth to do their geology with so little regard for the philosophical underpinnings of their science. Here, also, we perhaps have an explanation for the fact that many of those geologists who have reflected on the philosphy of their discipline have come from that extremity of the geological gender scale possessed of the least machismo - the subdiscipline of geomorphology. Names of such individuals that instantly spring to mind are G. K. Gilbert, W. M. Davis, T. C. Chamberlin, D. W. Johnson and J. H. Mackin. To those names there now has to be added that of S. A. Schumm.

Stanley Schumm has for several decades been one of the world's leading figures in the field of process geomor- phology. With a wealth of practical field and laboratory experience behind him, he has now added to his oeuvre this broadly philosophical monograph intended to assist young Earth and environmental scientists standing on the threshold of a research career. It is a volume entirely without pretension. On the one hand, it disregards such important issues as the nature of geological truth or the rational basis for uniformitarianism, and Schumm freely admits that philosophers may find his volume somewhat lacking in depth. He certainly draws heavily on the work of such familiar figures as Beveridge, Chamberlin, Feyerabend, Gilbert, Kuhn, Medawar and Popper.

On the other hand, Schumm is not here concerned with methodological niceties at the level of the choice of maps suitable for exercises in morphometry or the principles that should guide the laboratory simulation of real-world processes. His objective lies midway between these two extremes and the heart of the volume consists of a parade of ten types of problem that may confront a student of the Earth's surface. Allusion to just three of these problems will serve to illustrate their genre.

There is the problem of 'location', which concerns the difficulty of extrapolating results from one observational site to another; there is the problem of 'convergence', when very different terrestrial processes yield similar effects; and there is the problem of 'singularity', where unexpected variation occurs between datasets. In discussing the ten problems, Schumm seeks to demonstrate that although there is no set of procedures that we may justly hail as embodying 'the scientific method', there is something that we may reasonably term 'the scientific approach'. It is this approach, Schumm suggests, that is the hallmark of the successful scientist; and it is this approach that Schumm here seeks to inculcate in his readers.

He presents his views both interestingly and effectively and the volume will serve as a useful vade-mecum for all those aspiring to an understanding of geomorphic processes. These individuals will turn to it for inspiration in moments of vacuousness and for guidance in moments of tribulation. The extensive bibliography may even encourage them to seek a deeper understanding not only of the character of their chosen specialism, but also of the very nature of science itself. Only once in these pages was my ire aroused. On page 56 the name of one of France's greatest geologists has become horribly mutilé. I refer to Alexandre Brongniart.

But if we study Schumm's words diligently, and apply his precepts rigorously, will we unfailingly arrive at geological truth? As I read the volume, I carried in my mind the famed controversy that raged around 1800 over the origin of valleys. Which came first, the river or its valley? Were valleys ancient features and thus the progenitors of the occupying rivers or were they erosional features created by the resident rivers? Many eminent and experienced men favoured the former view, among them the Genevese geologist Jean André de Luc. It was de Luc who adduced a seemingly incontrovertible argument against the erosional hypothesis. If a valley contains a lake, he reasoned, then that lake is a natural settling basin for all the debris fluvially eroded from the valley upstream. Because the volume of sediment in such lakes is insignificant compared with the volume of the valley upstream, it would seem to follow that the valley upstream could never have been the work of the fluvial processes. De Luc died in 1817, more than 40 years before the advent of the glacial erosion theory inspired a recognition that the lake basins that had seemed so crucial are really of glacial origin and much younger than the containing valley. They have little if any relevance to the debate in which de Luc was involved. Now what I wonder is this: if Schumm's volume could have been placed in de Luc's hands in 1800 , might its sound advice have rescued him and his confrères from their error? I think not. We are all of us prisoners of the age in which we live and our thought processes are shaped by the milieu to which we belong. We need to remember that knowledge of the Earth processes is not something that gradually seeps out of the Earth's surface to await the human harvester. Rather, that knowledge is created within fallible human minds as their owners gaze out upon the natural world.

\section{Eleventh way}

Schumm's volume will greatly assist all such observers in their reasoning, but at the same time we need to be mindful of our own inadequacies. That wise man John Ruskin in 1869 observed: "For the more I endeavour to read Nature patiently, the more I find that she is always trying to deceive us". Perhaps Schumm should have added to his monograph an eleventh source of error in our efforts to understand this Earth. That source of error is insurmountable. It is our humanity.

Gordon L. Herries Davies is an emeritus fellow of Trinity College, University of Dublin, Dublin 2, Ireland.

- In the second edition of Continents in Motion, Walter Sullivan presents a history of the idea of continental drift. AIP/Adam Hilger. Price $\$ 50, £ 34.50$ (hbk); $\$ 25, £ 17.50$ (pbk). 